\title{
The morphological discrimination of microfilariae of Onchocerca volvulus from Mansonella ozzardi
}

\author{
R. J. POST ${ }^{1 *}$, Z. ADAMS ${ }^{1}$, A. J. SHELLEY', M. MAIA-HERZOG ${ }^{2}$, A. P. A. LUNA DIAS ${ }^{2}$ \\ and $\mathrm{S}$. COSCARÓN ${ }^{3}$ \\ ${ }^{1}$ Department of Entomology, The Natural History Museum, Cromwell Road, London SW7 5BD, UK \\ ${ }^{2}$ Departamento de Entomologia, FIOCRUZ, Ministério da Saúde, Avenida Brasil 4365, 21045-900 Rio de Faneiro, Brazil \\ ${ }^{3}$ Museo La Plata, Paseo del Bosque, La Plata, Argentina
}

(Received 14 October 2002; revised 21 Fanuary 2003; accepted 21 fanuary 2003)

\section{SUMMARY}

There is no published account which allows the morphological discrimination of microfilariae of Onchocerca volvulus and M. ozzardi from each other. However, they occur together in parts of Brazil and Venezuela, and presumably there is always the possibility that migration could establish new sympatric populations in the future. The objective of this study was to evaluate simple morphological characters that might be used for species-diagnosis of microfilariae. The conclusions were that the location of microfilariae in the blood or skin, the body size and the nucleation of the nerve ring are expected to be useful first indications of species identity, but cannot be used for confident diagnosis. The structure of the cephalic armature (stained with alcian blue) seems to be species specific, but is of limited application because it is often difficult to see. However, the pattern of nucleation of the tail (as expressed by the ratio of the length of the terminal nucleus compared with the length of the tail space) is distinctive and is expected to be diagnostic.

Key words: onchocerciasis, mansonelliasis, diagnosis, identification, Brazil.

\section{INTRODUCTION}

Microfilariae of Mansonella ozzardi (Manson, 1897) have been reported to occur in the skin as well as in the peripheral blood (Moraes, 1976; Ewert, Smith \& Corredor, 1981 ; Moraes et al. 1983). However, most modern and historical textbooks of parasitology or tropical medicine do not seem to recognize this, and often describe the occurrence in blood as a part of the diagnostic process (e.g. Coombs \& Crompton, 1991; Garcia, 1999, 2001; Maegraith, 1980; Muller, 2002; Peters \& Pasvol, 2002; WHO, 1997). There are a few exceptions which do mention the occurrence of $M$. ozzardi microfilariae in skin, but for various reasons they still do not contain sufficient other information for identification (e.g. Chiodini, Moody \& Manser, 2001; Cook, 1996; Crewe, 2002). Hence there is a real risk of misidentification of $M$. ozzardi during clinical examination of patients for the better known skin-dwelling microfilariae such as Onchocerca volvulus (Leuckart, 1893). This sort of problem led to the initial misidentification of $M$. streptocerca for $O$. volvulus in Uganda where $M$. streptocerca was not expected (Fischer et al. 1998). Mansonella ozzardi and $O$. volvulus are only known to be sympatric in the Amazonian focus of onchocerciasis which straddles the Brazil-Venezuela

* Corresponding author: Department of Entomology, The Natural History Museum, Cromwell Road, London SW7 5BD, UK. Tel: +44(0)20 7942 5593. Fax: +44(0)207942 5229. E-mail:r.post@nhm.ac.uk frontier (Fig. 1), but in view of the apparent potential for the spread of onchocerciasis through human migration, and the actual discovery of a new (but possibly temporary) focus of the disease in central Brazil (Maia-Herzog et al. 1999), it should not be assumed that outside the Amazonian focus there will be no problems. Hence, when Chamon et al. (1999) reported corneal eye lesions associated with $M$. ozzardi in a different part of the Brazilian Amazon it was necessary to confirm that $O$. volvulus was not implicated, and this was achieved partly through the development of a new molecular (DNA) assay (Morales-Hojas et al. 2001). Another complication for diagnosis is that $O$. volvulus can be found in the peripheral blood of up to one-third of infected people in hyperendemic communities (WHO, 1987), and this further increases the possibility of not detecting mixed infections.

Of course the morphology of the adults and microfilariae of $M$. ozzardi has been described (Orihel \& Eberhard, 1982; Kozek, Eberhard \& Raccurt, 1983), but in view of the lack of recognition that M. ozzardi commonly occurs in the skin there is no account that specifically compares the morphology of microfilariae of $M$. ozzardi and O. volvulus for the purposes of distinguishing these two species when they might occur together in a skin biopsy (or peripheral blood sample). However, most standard texts refer to the body size (length and sometimes width) and the pattern of nucleation of the tail. There is no doubt that the microfilariae of $M$. ozzardi are smaller than those of $O$. volvulus, but most texts also 


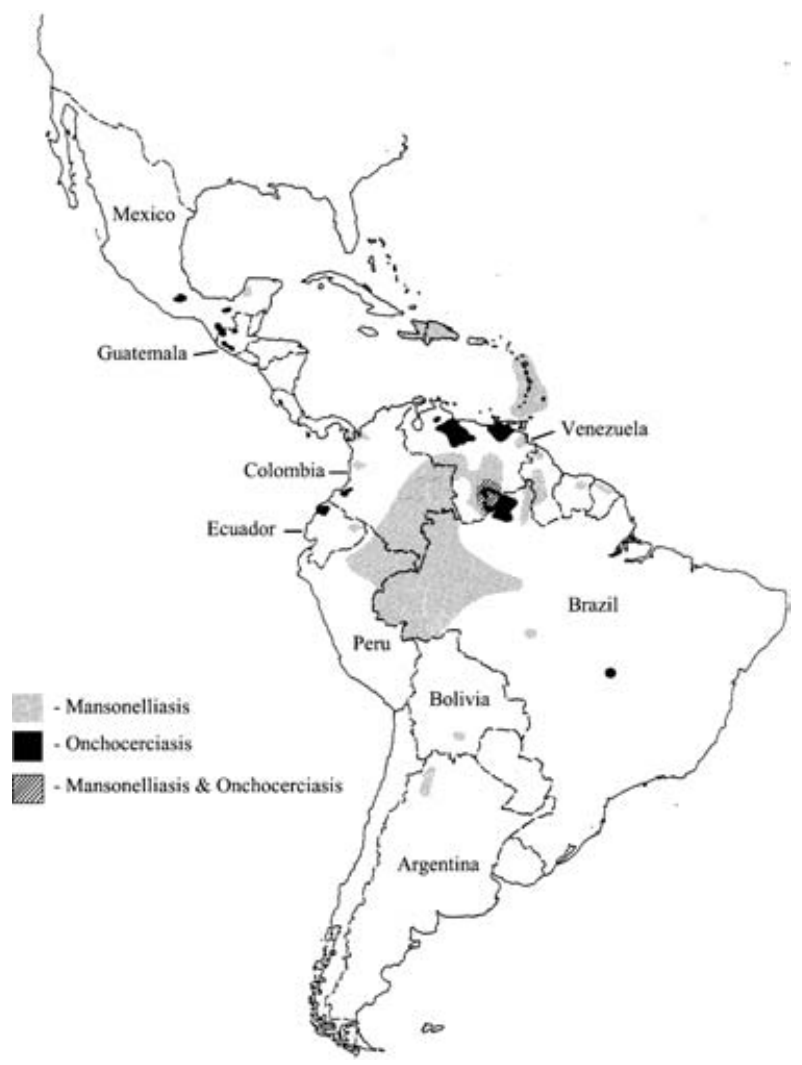

Fig. 1. Geographical distribution of Onchocerca volvulus and Mansonella ozzardi in America.

indicate that their ranges overlap. With regards to nucleation of the tail most standard texts simply indicate that there is an anucleate tail space in both species (unlike other human unsheathed microfilariae such as $M$. perstans). However, the drawings (but not the text) of Faust, Russell \& Jung (1970) seem to indicate that the length of the tail space and the last nucleus might be different. Kozek et al. (1983) described the terminal nucleus of $M$. ozzardi from both Haiti and Colombia as elongated and possibly species specific. Another interesting feature of the illustrations of the standard textbooks is that they often show $M$. ozzardi with little or no anucleate nerve ring, whereas in $O$. volvulus the gap is always well illustrated. Both $M$. ozzardi and $O$. volvulus have a finely striated cuticle (Bain, 1969; Kozek \& Raccurt, 1983) but there have also been reports of larger annular rings in the cuticle of $M$. ozzardi. However, Chadee et al. (1994) came to the conclusion that these annular rings were artifacts of the method of preparation. Laurence \& Simpson (1968) described different shapes of the cephalic armature for M.ozzardi and $O$. volvulus when stained with alcian blue. Finally, the movement of microfilariae emerging from skin snips has been found to be useful in distinguishing between $O$. volvulus and $M$. streptocerca in Africa (Muller, 2002), with O. volvulus being much more active and faster moving than $M$. streptocerca. However, Shelley, Maia-Herzog \& Calvão-Brito (2001) found no difference between the movement of microfilariae of $O$. volvulus and $M$. ozzardi in Brazil.

Molecular identification represents an alternative to morphological examination, but immunodiagnostic methods which have been used for the successful detection of $O$. volvulus elsewhere have either failed when tested against $M$. ozzardi in infected human populations (Shelley et al. 2001 ; Cabrera et al. 1989), or they have yet to be extensively tested (e.g. Ngu et al. 1998). Morales-Hojas et al. (2001) have developed and tested a molecular assay based on species-specific PCR amplification of part of the internal transcribed spacer region (ITS2) of the nuclear ribosomal DNA. This seems to be specific and at least as sensitive as microscopical examination of capillary blood. This high sensitivity was surprising because Raccurt et al. (1982) had estimated that examination of skin biopsies was only $35 \%$ as sensitive as examination of blood. The difference was most likely due to the different ways in which the skin biopsies were examined. The traditional method (as used by Raccurt et al. 1982) involves incubating the skin biopsy in a suitable fluid and then counting the number of microfilariae which emerge, but it has been established for $O$. volvulus that many microfilariae remain inside the biopsy and are therefore undetected (Schulz-Key, 1978; Taylor et al. 1989). The molecular method on the other hand involves the extraction of DNA from the whole (unincubated) skin biopsy and the subsequent detection of parasite DNA. Thus all microfilariae existing within a skin biopsy are available to be detected.

The objective of this study was to evaluate simple morphological characters that might be used for species-diagnosis of microfilariae of $O$. volvulus and M. ozzardi. We have examined a mixture of new characters and characters which appear to be potentially species specific from examination of the literature (see above). Mansonella perstans (Manson, 1891) has also been reported from peripheral blood samples from Mexico, Panama, Colombia, Venezuela, Guyana, Surinam, French Guiana, Trinidad and some of the other Caribbean islands (Hawking, 1979). A single infection has been reported from Roraima state in Brazil outside the Amazonian onchocerciasis focus, but this was probably not autochthonous (Oliveira, 1963). In any case, $M$. perstans does not present an identification problem because the unsheathed microfilariae (which unlike $M$. ozzardi really are only found in blood) are easily identified by their tails which end bluntly and have nuclei to the tip (see for example Muller, 2002; WHO, 1997).

\section{MATERIALS AND METHODS}

A nodule of $O$. volvulus was supplied by Dr Renerys from a Yanomami Indian at the Indian Hospital in Boa Vista in Roraima State Brazil (near the 
Table 1. Measurements (in $\mu \mathrm{m}$ ) of microfilariae of Onchocerca volvulus and Mansonella ozzardi

\begin{tabular}{|c|c|c|c|c|c|c|c|c|c|c|c|c|c|c|}
\hline \multirow[b]{3}{*}{ Sample } & \multirow[b]{3}{*}{ Tissue } & \multicolumn{2}{|c|}{ Body length } & \multirow{3}{*}{$\begin{array}{l}\text { Sample } \\
\text { size }\end{array}$} & \multirow{3}{*}{$\begin{array}{l}\text { Cephalic } \\
\text { space }\end{array}$} & \multirow{3}{*}{$\begin{array}{l}\text { Nerve } \\
\text { ring }\end{array}$} & \multirow{2}{*}{\multicolumn{4}{|c|}{ Tail width }} & \multirow{3}{*}{$\begin{array}{l}\text { Terminal } \\
\text { nucleus } \\
\text { width }\end{array}$} & \multirow{3}{*}{$\begin{array}{l}\text { Terminal } \\
\text { nucleus } \\
\text { length }\end{array}$} & \multirow[b]{3}{*}{ Tail space } & \multirow[b]{3}{*}{$\mathrm{ts} / \mathrm{tnl} \mathbf{l}^{*}$} \\
\hline & & Sample & Mean & & & & & & & & & & & \\
\hline & & size & (range) & & & & 1 & 2 & 3 & 4 & & & & \\
\hline \multicolumn{15}{|l|}{ O. volvulus } \\
\hline Yanomami & Skin & 5 & $\begin{array}{l}259 \\
(252-267)\end{array}$ & 8 & $\begin{array}{l}8 \cdot 1 \\
(6 \cdot 7-9 \cdot 6)\end{array}$ & $\begin{array}{l}5 \cdot 9 \\
(5 \cdot 3-6 \cdot 7)\end{array}$ & $\begin{array}{l}2 \cdot 0 \\
(1 \cdot 4-2 \cdot 4)\end{array}$ & $\begin{array}{l}2 \cdot 1 \\
(1 \cdot 4-2 \cdot 4)\end{array}$ & $\begin{array}{l}2 \cdot 7 \\
(2 \cdot 4-2 \cdot 9)\end{array}$ & $\begin{array}{l}4 \cdot 3 \\
(3 \cdot 9-4 \cdot 8)\end{array}$ & $\begin{array}{l}1 \cdot 0 \\
(0 \cdot 9-1 \cdot 3)\end{array}$ & $\begin{array}{l}2 \cdot 6 \\
(2 \cdot 2-3 \cdot 5)\end{array}$ & $\begin{array}{l}11 \cdot 9 \\
(10 \cdot 5-13 \cdot 2)\end{array}$ & $\begin{array}{l}4 \cdot 6 \\
(3 \cdot 3-5 \cdot 0)\end{array}$ \\
\hline Boa Vista & Nodule & 29 & $\begin{array}{l}254 \\
(232-277)\end{array}$ & 50 & $\begin{array}{l}7 \cdot 0 \\
(5 \cdot 8-8 \cdot 2)\end{array}$ & $\begin{array}{l}5 \cdot 9 \\
(5 \cdot 8-6 \cdot 2)\end{array}$ & $\begin{array}{l}2 \cdot 0 \\
(1 \cdot 9-2 \cdot 4)\end{array}$ & $\begin{array}{l}2 \cdot 4 \\
(1 \cdot 9-2 \cdot 9)\end{array}$ & $\begin{array}{l}3 \cdot 0 \\
(2 \cdot 4-3 \cdot 4)\end{array}$ & $\begin{array}{l}4 \cdot 4 \\
(3 \cdot 8-4 \cdot 8)\end{array}$ & $\begin{array}{l}1 \cdot 0 \\
(0 \cdot 9-1 \cdot 3)\end{array}$ & $\begin{array}{l}3 \cdot 4 \\
(2 \cdot 2-5 \cdot 2)\end{array}$ & $\begin{array}{l}13 \cdot 1 \\
(9 \cdot 1-16 \cdot 5)\end{array}$ & $\begin{array}{l}4 \cdot 2 \\
(2 \cdot 0-6 \cdot 3)\end{array}$ \\
\hline Xitei & Skin & 33 & $\begin{array}{l}251 \\
(186-286)\end{array}$ & 16 & $\begin{array}{l}8 \cdot 1 \\
(6 \cdot 7-9 \cdot 6)\end{array}$ & $\begin{array}{l}5 \cdot 6 \\
(4 \cdot 8-6 \cdot 7)\end{array}$ & $\begin{array}{l}1.9 \\
(1 \cdot 4-1 \cdot 9)\end{array}$ & $\begin{array}{l}2 \cdot 0 \\
(1 \cdot 9-2 \cdot 4)\end{array}$ & $\begin{array}{l}2 \cdot 6 \\
(2 \cdot 4-3 \cdot 4)\end{array}$ & $\begin{array}{l}4 \cdot 1 \\
(3 \cdot 1-4 \cdot 1)\end{array}$ & $\begin{array}{l}1 \cdot 0 \\
(0 \cdot 9-1 \cdot 3)\end{array}$ & $\begin{array}{l}2 \cdot 7 \\
(2 \cdot 2-4 \cdot 4)\end{array}$ & $\begin{array}{l}11 \cdot 8 \\
(8 \cdot 3-14 \cdot 0)\end{array}$ & $\begin{array}{l}4 \cdot 5 \\
(2 \cdot 9-5 \cdot 6)\end{array}$ \\
\hline Total & & 88 & $\begin{array}{l}253 \\
(186-286)\end{array}$ & 53 & $\begin{array}{l}7 \cdot 5 \\
(5 \cdot 8-9 \cdot 6)\end{array}$ & $\begin{array}{l}5 \cdot 8 \\
(4 \cdot 8-6 \cdot 7)\end{array}$ & $\begin{array}{l}1 \cdot 9 \\
(1 \cdot 4-2 \cdot 4)\end{array}$ & $\begin{array}{l}2 \cdot 3 \\
(1 \cdot 4-2 \cdot 9)\end{array}$ & $\begin{array}{l}2 \cdot 8 \\
(2 \cdot 4-3 \cdot 4)\end{array}$ & $\begin{array}{l}4 \cdot 4 \\
(3 \cdot 1-4 \cdot 8)\end{array}$ & $\begin{array}{l}1 \cdot 0 \\
(0 \cdot 9-1 \cdot 3)\end{array}$ & $\begin{array}{l}3 \cdot 1 \\
(2 \cdot 2-5 \cdot 2)\end{array}$ & $\begin{array}{l}12 \cdot 6 \\
(8 \cdot 3-16 \cdot 5)\end{array}$ & $\begin{array}{l}4 \cdot 3 \\
(2 \cdot 0-6 \cdot 3)\end{array}$ \\
\hline \multicolumn{15}{|l|}{ M. ozzardi } \\
\hline Normenta† & Blood smear & 50 & $\begin{array}{l}195 \\
(176-211)\end{array}$ & 0 & - & - & - & - & - & - & - & - & - & - \\
\hline Normenta & $\begin{array}{l}\text { Haemoglobin-free } \\
\text { blood }\end{array}$ & 50 & $\begin{array}{l}193 \\
(165-228)\end{array}$ & 6 & $\begin{array}{l}4 \cdot 2 \\
(3 \cdot 8-4 \cdot 8)\end{array}$ & $\begin{array}{l}4 \cdot 6 \\
(4 \cdot 3-4 \cdot 8)\end{array}$ & $\begin{array}{l}1 \cdot 0 \\
(1 \cdot 0-1 \cdot 4)\end{array}$ & $\begin{array}{l}1 \cdot 4 \\
(1 \cdot 4-1 \cdot 4)\end{array}$ & $\begin{array}{l}1 \cdot 8 \\
(1 \cdot 4-1 \cdot 9)\end{array}$ & $\begin{array}{l}3 \cdot 2 \\
(2 \cdot 9-3 \cdot 4)\end{array}$ & $\begin{array}{l}1 \cdot 0 \\
(0 \cdot 9-1 \cdot 3)\end{array}$ & $\begin{array}{l}6 \cdot 7 \\
(4 \cdot 8-7 \cdot 9)\end{array}$ & $\begin{array}{l}5 \cdot 4 \\
(4 \cdot 4-7 \cdot 9)\end{array}$ & $\begin{array}{l}0 \cdot 9 \\
(0 \cdot 7-1 \cdot 6)\end{array}$ \\
\hline Acre $\dagger$ & Skin & 36 & $\begin{array}{l}171 \\
(149-202)\end{array}$ & 0 & - & - & - & - & - & - & - & - & - & - \\
\hline $\begin{array}{l}\text { Pauini and } \\
\text { Labrea }\end{array}$ & Skin & 33 & $\begin{array}{l}195 \\
(168-224)\end{array}$ & 19 & $\begin{array}{l}5 \cdot 2 \\
(3 \cdot 8-6 \cdot 7)\end{array}$ & $\begin{array}{l}3 \cdot 9 \\
(2 \cdot 4-5 \cdot 3)\end{array}$ & $\begin{array}{l}1 \cdot 0 \\
(0 \cdot 5-1 \cdot 4)\end{array}$ & $\begin{array}{l}1 \cdot 3 \\
(1 \cdot 0-1 \cdot 4)\end{array}$ & $\begin{array}{l}1 \cdot 6 \\
(1 \cdot 4-1 \cdot 9)\end{array}$ & $\begin{array}{l}2 \cdot 9 \\
(2 \cdot 4-3 \cdot 4)\end{array}$ & $\begin{array}{l}0 \cdot 8 \\
(0 \cdot 4-1 \cdot 3)\end{array}$ & $\begin{array}{l}5 \cdot 5 \\
(4 \cdot 4-7 \cdot 0)\end{array}$ & $\begin{array}{l}5 \cdot 7 \\
(3 \cdot 1-8 \cdot 4)\end{array}$ & $\begin{array}{l}1 \cdot 0 \\
(0 \cdot 5-1 \cdot 4)\end{array}$ \\
\hline Total & & 169 & $\begin{array}{l}189 \\
(149-228)\end{array}$ & 25 & $\begin{array}{l}5 \cdot 0 \\
(3 \cdot 8-6 \cdot 7)\end{array}$ & $\begin{array}{l}4 \cdot 1 \\
(2 \cdot 4-5 \cdot 3)\end{array}$ & $\begin{array}{l}1 \cdot 0 \\
(0 \cdot 5-1 \cdot 4)\end{array}$ & $\begin{array}{l}1 \cdot 3 \\
(1 \cdot 0-1 \cdot 4)\end{array}$ & $\begin{array}{l}1 \cdot 7 \\
(1 \cdot 4-1 \cdot 9)\end{array}$ & $\begin{array}{l}2 \cdot 9 \\
(2 \cdot 4-3 \cdot 4)\end{array}$ & $\begin{array}{l}0 \cdot 9 \\
(0 \cdot 4-1 \cdot 3)\end{array}$ & $\begin{array}{l}5 \cdot 8 \\
(4 \cdot 4-7 \cdot 9)\end{array}$ & $\begin{array}{l}5 \cdot 6 \\
(3 \cdot 1-8 \cdot 4)\end{array}$ & $\begin{array}{l}1 \cdot 0 \\
(0 \cdot 5-1 \cdot 6)\end{array}$ \\
\hline
\end{tabular}

* ts/tnl is the ratio of the length of the tail space and the terminal nucleus.

$\dagger$ The microfilariae from the blood smear from Normenta and the skin biopsies from Acre were not well enough preserved to enable measurements other than total body length. 

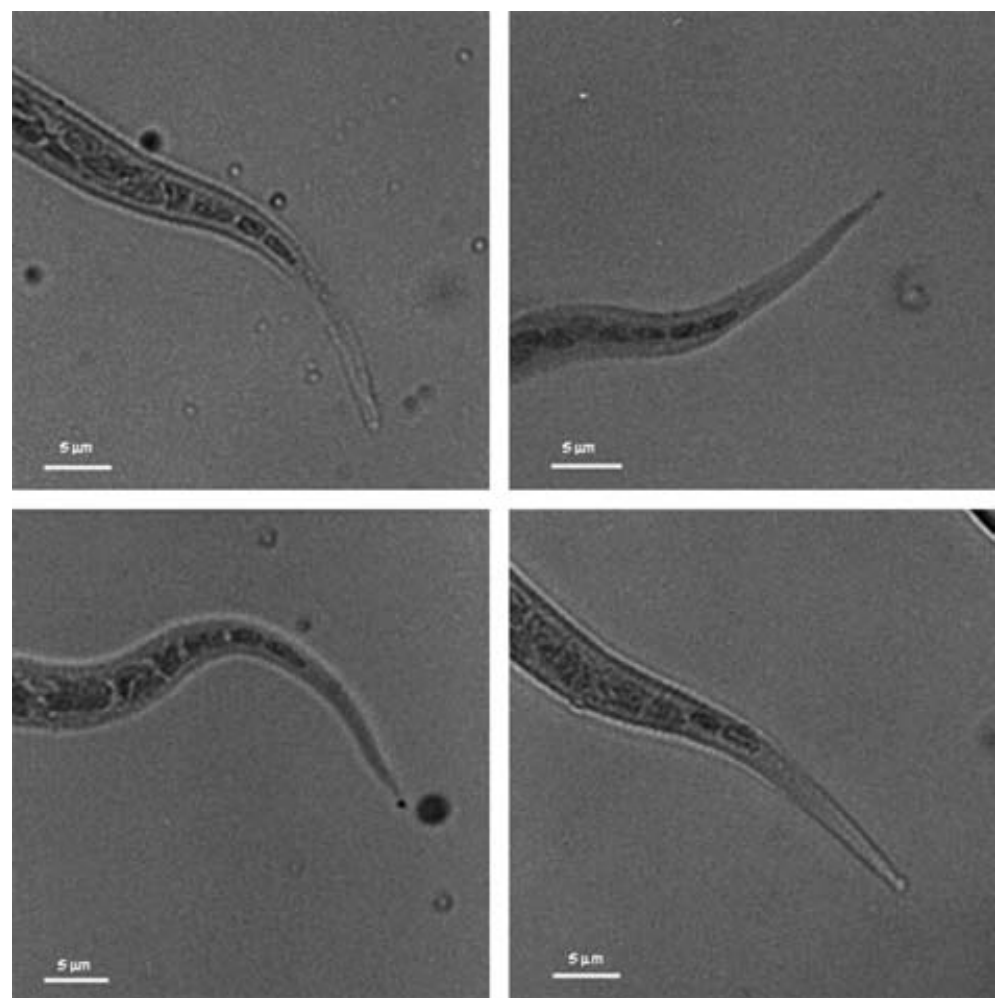

Fig. 2. Tails of four microfilariae of Onchocerca volvulus stained with lactopropionic orcein to show nucleation.
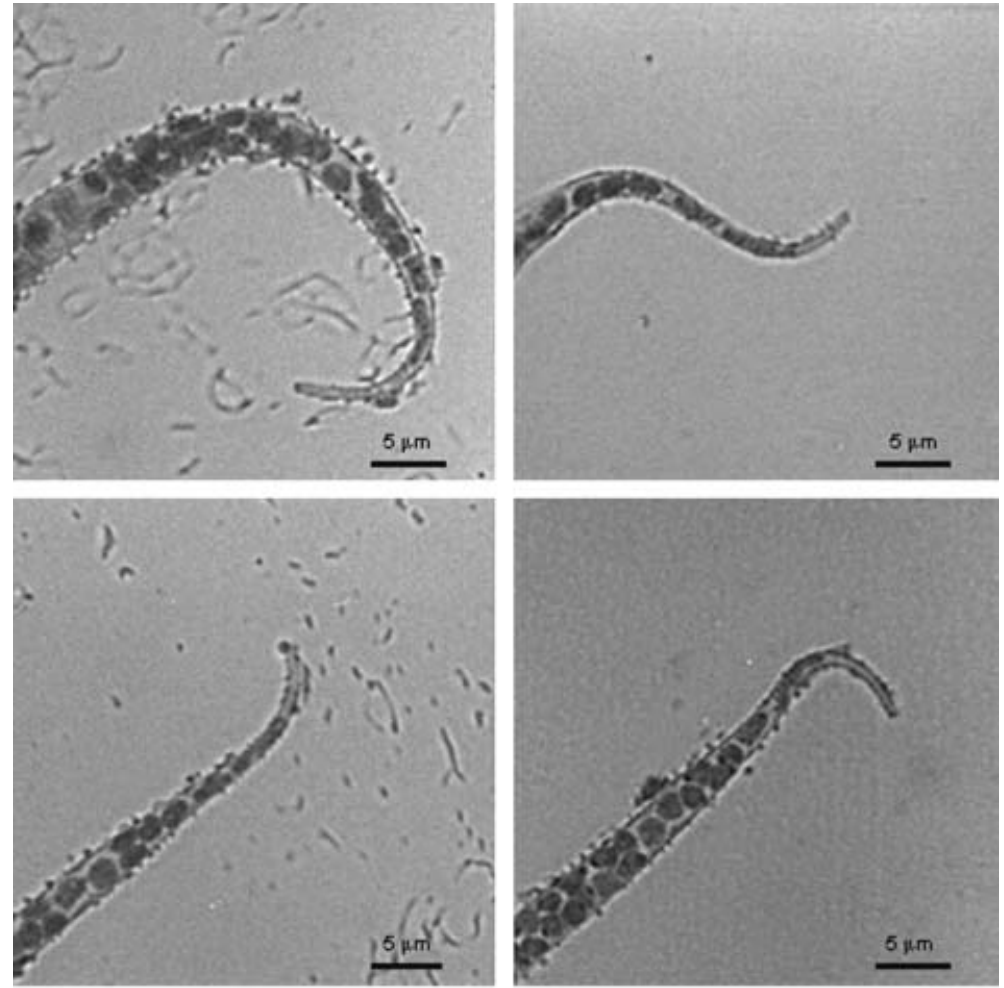

Fig. 3. Tails of four microfilariae of Mansonella ozzardi stained with lactopropionic orcein to show nucleation.

Amazonian onchocerciasis focus) on 26 April 1999. Nodules were preserved in ethanol and microfilariae obtained by pulling out broken lengths of adult female worms and squeezing out their body contents into ethanol which could then be dropped onto a microscope slide. Thus, mature (stretched) microfilariae would have come from the uterus of the adult females, but they could be easily separated from earlier immature (unhatched) stages (Schulz-Key, Jean \& Albiez, 1980). 


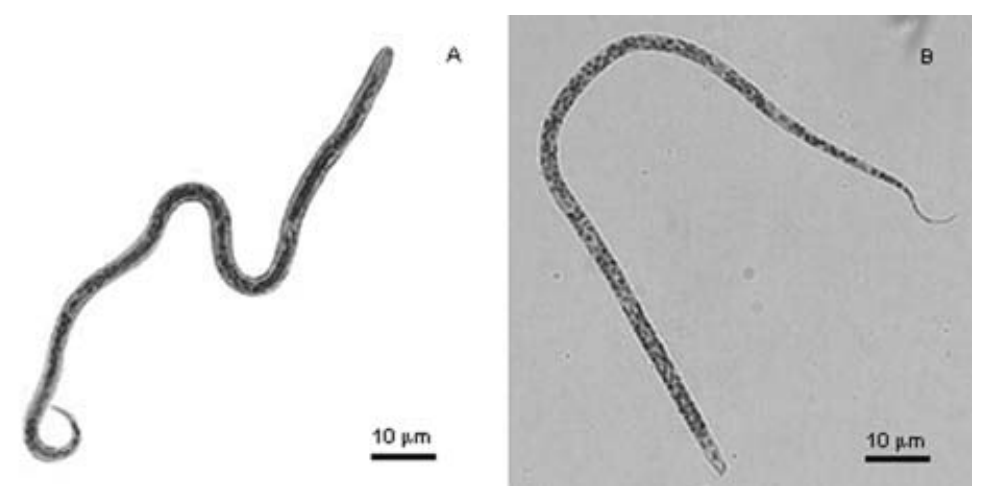

Fig. 4. Whole microfilariae of Onchocerca volvulus (A) and Mansonella ozzardi (B) stained with lactopropionic orcein.
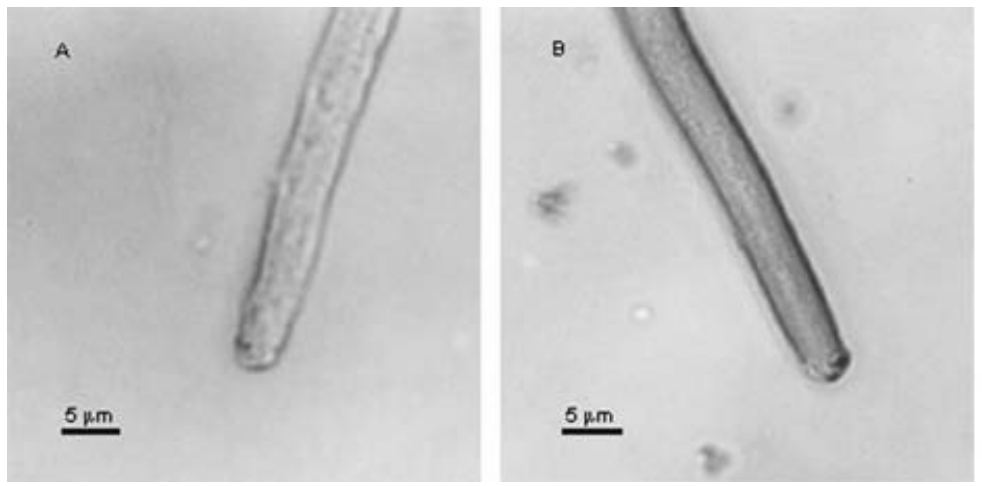

Fig. 5. Cephalic armature of Mansonella ozzardi (A) and Onchocerca volvulus (B) stained with alcian blue.

Two samples of M. ozzardi microfilariae were obtained from blood of a heavily infected person from Normenta in Jujuy Province in northern Argentina on 26 January 1998. Firstly, a pool of microfilariae was obtained from $20 \mathrm{ml}$ of blood removed by syringe. Haemoglobin was removed and the blood centrifuged to lightly pellet the microfilariae. These were then resuspended and preserved in absolute ethanol, and then dropped onto a microscope slide. Secondly, a thick blood film was prepared and dried for later examination.

Skin biopsies were obtained using a corneoscleral punch from within the Brazilian Amazonian onchocerciasis focus by J. C. M. Schuertz from Xitei (Roraima State) in November 1999, and outside the onchocerciasis focus from Antimari (River Acre, Acre State), Labrea and Pauini (both on the River Purus in Amazonas State), a region where Chamon et al. (1999) had reported eye lesions associated with M. ozzardi. Skin biopsies from Antimari (October 1998), Labrea and Pauini (both August 1999) were incubated for $30 \mathrm{~min}$ in distilled water (for microscopical examination for emergent microfilariae) and subsequently preserved in ethanol. Skin biopsies from Xitei were preserved directly into ethanol without prior incubation. In the laboratory, microfilariae were extracted from preserved skin biopsies by collagenase digestion according to Schulz-Key (1978).
Microfilariae in a drop of alcohol or collagenase digestion solution were normally mixed with a drop of lacto-acetic orcein and allowed to stain for approximately $10 \mathrm{~min}$ before adding the cover-slip and examining under the microscope at $\times 400-\times 1000$ magnification with bright-field illumination.

Orcein-stained microfilariae were measured to determine total length, length of cephalic space, width at nerve ring, width of the terminal nucleus, length of the terminal nucleus, length of the tail space and shape of the tail. The shape of the tail was initially compared between 2 microfilariae of $O$. volvulus from skin snips from different infected persons from the Amazonian onchocerciasis focus, and 2 microfilariae of $M$. ozzardi from the pool from Argentina. The width of the tail was measured at $12 \times 0.96 \mu \mathrm{m}$ intervals from the tip to estimate the point of maximum width difference (which was $2 \cdot 16 \mu \mathrm{m}$ at a point $6.71 \mu \mathrm{m}$ from the tip of the tail). Subsequently, regular width measurements were made at the distal (tw1) and proximal (tw2) ends of the last nucleus, the proximal end of the penultimate nucleus (tw3) and $6.71 \mu \mathrm{m}$ from the tip of the tail (tw4). As well as the measurements the distribution and shape of the nucleii in the head, nerve ring and tail was observed and illustrated.

Microfilariae of O. volvulus from Boa Vista (nodule) and $M$. ozzardi from Argentina were stained with alcian blue to show the cephalic armature 
according to methods described by Laurence \& Simpson (1968) and Garms (1985). These small structures were observed under the microscope at $\times 1000$ magnification bright field illumination.

\section{RESULTS}

The measurements of $O$. volvulus and $M$. ozzardi are presented in Table 1. The body length, length of the cephalic space and width at the nerve ring indicate that $M$. ozzardi is generally smaller than $O$. volvulus, but there are overlaps in the ranges of all these characters. The 4 tail width measurements also indicate that $M$. ozzardi is simply smaller, but the data for tw1, tw2 and tw 3 show no overlap between the species, and of these tw 3 (width of body at proximal end of penultimate nucleus) is most distinctive. The average lengths of the terminal nucleus and the tail space are very different, although they overlap between the species. To examine the differences in nucleation of the tail the ratio of the length of the terminal nucleus to its width was compared, and found to have overlapping ranges. However, the ratio of the length of the tail space (which was on average longer in $O$. volvulus) to the length of the terminal nucleus (which was on average shorter in $O$. volvulus) was found to be very distinctive and the ranges did not overlap $(O$. volvulus mean $=4 \cdot 3$, range $2 \cdot 00-6 \cdot 33 ; M$. ozzardi mean $=1 \cdot 00$, range $0 \cdot 53-1 \cdot 64)$. The appearance of these differences is illustrated in Figs 2 and 3.

Examination of the cephalic space revealed no differences in the pattern of nucleation, but there was some difference in the pattern of nucleation of the nerve ring. In all $O$. volvulus examined $(n=56)$ the nerve ring consisted of a distinctive anucleate gap. In a few specimens the gap was quite narrow, and in one it was narrow and bridged by a single nucleus. By contrast, in $M$. ozzardi $(n=21)$ the nerve ring was always narrow to such an extent that there was often no distinct anucleate area (Fig. 4).

The cephalic armature did not always stain well with alcian blue, but in the best specimens it was clear that there was a difference between the two species (Fig. 5), and that this was the same as that originally described and illustrated by Laurence $\&$ Simpson (1968).

\section{DISCUSSION}

The method of specimen preparation is known to have a large effect on microfilariae body-size measurements (Bain, 1969; WHO, 1997), but our length measurements for $O$. volvulus (range 186$286 \mu \mathrm{m}$ ) and $M$. ozzardi (range 149-228 $\mu \mathrm{m}$ ) are comparable with those published by previous authors. For example, for O. volvulus Bain (1969) gave a range of $230-270 \mu \mathrm{m}$ and Muller (2002) gave 280-330 $\mu \mathrm{m}$. For M. ozzardi Crewe (2002) gave
200-225 $\mu \mathrm{m}$ and Muller (2002) gave 175-240 $\mu \mathrm{m}$. Our results confirm that $O$. volvulus is usually larger than $M$. ozzardi for a number of body measurements, but that the ranges overlap (or are likely to overlap with larger samples). Body size of microfilariae is therefore a useful indication of species identity, but is not sufficiently different for definitive diagnosis.

In $98 \%$ of microfilariae of $O$. volvulus there was a distinctive anucleate nerve ring, whereas $43 \%$ of $M$. ozzardi showed no distinctive anucleated gap at the nerve ring. Hence the nucleation of the nerve ring is a useful first indication of species identity, but it is not sufficiently different for definitive diagnosis.

The structure of the cephalic armature as revealed by alcian blue was clearly different between the species (as described by Laurence \& Simpson, 1968), and might also be useful for identification of L1 larvae from the vector because it persists into that stage (Garms, 1985). However, it did not stain clearly in many specimens, and even when it does stain well it is a very small structure at the limits of visibility using standard laboratory microscopes at $\times 1000$ magnification.

The nucleation of the tail was found to be speciesspecific and should be diagnostic. The average length of the terminal nucleus (longer in $M . o z z a r d i$ ) and tail space (longer in $O$. volvulus) were quite different, but the ranges overlapped, whereas the ratio of the two measures showed a 4 -fold mean difference with distinctive non-overlapping ranges. This character can be expected to be diagnostic.

We would like to thank Dr Renerys and J. C. M. Schuertz, for helping us to obtain some of the parasite material, and C. A. Lowry for help in preparing Fig. 4.

\section{REFERENCES}

BAIN, O. (1969). Morphologie des stades larvaires d' Onchocerca volvulus chez Simulium domnosum et redescription de la microfilaire. Annales de Parasitologie 44, 69-82.

CABrera, Z., PARKHOUSE, R. M. E., FORSYTH, K., GOMEZ Priego, A., PABOn, R. \& YARZABal, L. (1989). Specific detection of human antibodies to Onchocerca volvulus. Tropical Medicine and Parasitology 40, 454-459.

CHADEE, D. D., RAWlins, S. C., DOON, R. \& BABOOlal, S. (1994). Presence of annular rings on Mansonella ozzardi microfilariae. Transactions of the Royal Society of Tropical Medicine and Hygiene 88, 356.

CHAMON, W., BRANCO, B. C., BELFORT, R., KUBOFCIK, J. \& Nutman, T. B. (1999). Corneal lesions associated with Mansonella ozzardi in the Brazilian Amazon. Investigative Ophthalmology and Visual Science 40, S264.

Chiodini, P. L., MOOdy, A. H. \& MAnser, D. W. (2001). Atlas of Medical Helminthology and Protozoology, 4th Edn.

Churchill Livingstone, Edinburgh.

CoOK, G. C. (1996). Manson's Tropical Diseases, 20th Edn.

WB Saunders Company Ltd, London. 
CoOmbs, I. \& CROMPton, D. W. T. (1991). A Guide to Human Helminths, 1st Edn. Taylor \& Francis, London.

CREWE, w. (2002). Mansonelliasis. In The Encyclopedia of Arthropod-Transmitted Infections (ed. Service, M. W.), pp. 327-333. CABI Publishing, Wallingford.

EWERT, A., SMITH, J. H. \& CORREDOR, A. (1981). The microfilariae of Mansonella ozzardi in human skin biopsies. American Fournal of Tropical Medicine and Hygiene 30, 988-991.

FaUst, E. C., RUSSELl, P. F. \& JUNG, R. C. (1970). Craig and Faust's Clinical Parasitology, 8th Edn. Lea \& Febiger, Philadelphia.

FISCHER, P., BÜTTNER, D. W., BAMUHIIGA, J. \& WILliams, S. A. (1998). Detection of the filarial parasite Mansonella streptocerca in skin biopsies by a nested polymerase chain reaction-based assay. American Fournal of Tropical Medicine and Hygiene 58, 816-820.

Garcia, L. s. (1999). Practical Guide to Diagnostic Parasitology, 1st Edn. ASM Press, Washington. Garcia, L. s. (2001). Diagnostic Medical Parasitology, 1st Edn. ASM Press, Washington.

GARMS, R. (1985). Morphological differentiation from Onchocerca volvulus of first stage larvae of an unknown filarial species commonly found in Simulium sanctipauli s.l. in Liberia. Tropical Medicine and Parasitology 36, 255-256.

HAWkiNG, F. (1979). The distribution of human filariasis throughout the world part IV. America. Tropical Diseases Bulletin 76, 693-710.

KOZEK, W. J. \& RACCURT, C. (1983). Ultrastructure of Mansonella ozzardi microfilariae, with a comparison of the South American (simuliid-transmitted) and Caribbean (culicoid-transmitted) forms. Tropenmedizin und Parasitologie 34, 38-53.

KOZEK, W. J., EBERHARD, M. L. \& RACCURT, C. (1983). Comparative morphology of Mansonella ozzardi microfilariae from Colombia and Haiti. A light microscopy study. Tropenmedizin und Parasitologie 34, 33-37.

LAURENCE, B. R. \& SIMPSON, M. G. (1968). Cephalic and pharyngeal structures in microfilariae revealed by staining. Fournal of Helminthology 42, 309-330. maegraith, B. (1980). Adams \& Maegraith: Clinical Tropical Diseases, 7th Edn. Blackwell, Oxford.

MAIA-HERZOG, M., SHELLEY, A. J., BRADLEY, J. E., LUNA Dias, A. P. A., CALVAO, R. H. S., LOWRY, C., CAMargo, M., RUBio, J. M., POST, R. J. \& COELHO, G. E. (1999). Discovery of a new focus of human onchocerciasis in central Brazil. Transactions of the Royal Society of Tropical Medicine and Hygiene 93, 235-239.

MORAES, M. A. P. (1976). Mansonella ozzardi microfilariae in skin snips. Transactions of the Royal Society of Tropical Medicine and Hygiene 70, 16.

MORAES, M. A. P., SHELley, A. J., LUNA DiAs, A.P. A. \& MANGabeira Silva, C. J. (1983). The concentration of
Mansonella ozzardi microfilariae in the skin capillaries. Transactions of the Royal Society of Tropical Medicine and Hygiene 77, 463-466.

MORALES HOJAS, R., POST, R. J., SHELLEY, A. J., MAIA-HERZOG, M., coscaron, S. \& CHEKe, R. A. (2001). Characterisation of nuclear ribosomal DNA sequences from Onchocerca volvulus and Mansonella ozzardi (Nematoda:

Filarioidea) and development of a PCR-based method for their detection in skin biopsies. International fournal for Parasitology 31, 169-177.

Muller, R. (2002). Worms and Human Disease, 2nd Edn. CABI Publishing, London Wallingford.

NGU, J. L., NKENFOU, C., CAPUli, E., MCMOLI, T. E., PERleR, F., Mbwagbor, J., TUme, C., NlatTe, B., DONFACK, J. \& ASONGany, T. (1998). Novel, sensitive and low-cost diagnostic tests for 'river blindness' - detection of specific antigens in tears, urine and dermal fluid. Tropical Medicine and International Health $\mathbf{3}$, 339-348.

OLIVEIRA, W. R. (1963). Infestação por filárias em habitantes de Vila Pereira, território de Roraima (Brasil). Revista do Instituto de Medicina Tropical de São Paulo 5, 287-288.

ORIHEL, T. C. \& EBERHARD, M. L. (1982). Mansonella ozzardi: a rediscription with comments on its taxonomic relationships. American Fournal of Tropical Medicine and Hygiene 31, 1142-1147.

PETERs, w. \& PASvol, G. (2002). Tropical Medicine and Parasitology, 5th Edn. Mosby, London.

RACCURT, C., LOWRIE, R. C., BONCY, J. \& KATZ, S. P. (1982). Mansonella ozzardi in Haiti. III. A comparison of the sensitivity of four sampling methods in detecting infections. American Yournal of Tropical Medicine and Hygiene 31, 275-279.

SHELlEy, A. J., MAIA-HERZOG, M. \& CALVÃO-BRITO, R. (2001). The specificity of an ELISA for detecting Onchocerca volvulus in Brazil. Transactions of the Royal Society of Tropical Medicine and Hygiene 95, 171-173.

SCHULZ-KEY, H. (1978). A simple technique to assess the total number of Onchocerca volvulus microfilariae in skin snips. Tropenmedizin und Parasitologie 29, 51-54.

SCHULZ-KEY, H., JEAN, B. \& ALBIEZ, E. J. (1980). Investigations on female Onchocerca volvulus for the evaluation of drug trials. Tropenmedizin und Parasitologie 31, 34-40.

TAYLOR, H. R., MUNOZ, B., KEYVAN-LARIJANI, E. \& GREENE, B. м. (1989). Reliability of detection of microfilariae in skin snips in the diagnosis of onchocerciasis. American Fournal of Tropical Medicine and Hygiene 41, 467-471.

WORLD HEALTH ORGANIZATION (1987). WHO Expert Committee on Onchocerciasis. Third Report. WHO Technical Report Series No. 752. WHO, Geneva. world health organization (1997). Bench Aids for the Diagnosis of Filarial Infections. WHO, Geneva. 